\begin{tabular}{ccc|} 
PEDIOMATERNAL \\
NURSING JOURNAL \\
Vol. 7, No. 2, September 2021 \\
Journal Homepage: https://e-journal.unair.ac.id/PMNJ/ \\
http://dx.doi.org/10.20473/pmnj.v7i2.23982
\end{tabular}

Original

\title{
The Effect of Lecture, Brainstorming, Demonstration Towards Breast Self-Examination Behavior Based on Health Belief Model
}

\author{
Emmy Mulyani $^{1}$, Mira Triharini ${ }^{2 *}{ }^{\mathbb{D}}$, Tiyas Kusumaningrum ${ }^{3} \mathbb{C}$ \\ ${ }^{1}$ Bachelor in Nursing Study Program, Faculty of Nursing, Universitas Airlangga, Surabaya, Indonesia \\ ${ }^{2}$ Department of Advanced Nursing, Faculty of Nursing, Universitas Airlangga, Surabaya, Indonesia \\ ${ }^{3}$ Department of Fundamental Nursing, Faculty of Nursing, Universitas Airlangga, Surabaya, Indonesia
}

\section{ARTICLE HISTORY}

Received : Desember 22, 2020

Revised : February 16, 2021

Accepted : July 18, 2021

Published : September 3, 2021

\section{KEYWORDS}

breast cancer; examination; early detection; woman

\section{CORRESPONDING AUTHOR}

*Mira Trihartini

mira-t@fkp.unair.ac.id

Department of Advanced

Nursing, Faculty of Nursing,

Universitas Airlangga,

Surabaya, Indonesia

Cite this as:

\section{ABSTRACT}

Introduction: Breast cancer is the leading cause of cancer-related disability and death in women due to a lack of education using Lecture, Brainstorming, Demonstration (LBD) on Breast Self-Examination (BSE) behaviour in adolescents.

Methods: This research was a quasi-experimental research with prepost treatment and control groups. Fifty-six respondents were selected by purposive sampling. Data were obtained using a questionnaire then analyzed using the Wilcoxon Signed Rank Test and the Mann Whitney U test with a significance level $\mathrm{p}<0.05$.

Results: LBD significantly improved BSE behaviour in young women by perceived susceptibility, perceived severity, perceived barrier, perceived benefit, and perceived self-efficacy $(\mathrm{p}=0.00)$.

Conclusion: Delivering LBD health education methods can boost perceived susceptibility, perceived severity, perceived barrier, perceived benefit, perceived self-efficacy of teenagers regarding SADARI behaviour. Teenagers are given health education to increase their knowledge of breast cancer.

Mulyani, M., Trihartini, M., \& Kusumaningrum, T. (2021). The Effect of Lecture, Brainstorming, Demonstration Towards Breast Self-Examination Behavior Based on Health Belief Model. Pediomaternal Nurs. J., 7(2), 92100. Doi: http://dx.doi.org/10.20473/pmnj.v7i2.23982

\section{INTRODUCTION}

Breast cancer is a significant cause of disability and cancer-related mortality in women (Abolfotouh et al., 2015). In addition, the factors such as lack of information about early detection and fast food consumption among teenagers increase the risk of breast cancer (Yani 2009).

Researchers have conducted a preliminary study in Senior High School 3 GOWA, Makassar on October 23, 2019, on 18 students with the outcome, respondents results showed that perceived susceptibility responses are still low where only $28 \%$ or about five teenagers stated that they are susceptible to breast cancer, perceived barriers which reached $72 \%$ or about 15 teenagers indicated that it is easy to do Breast Self-Examination (BSE) or Periksa Payudara Sendiri (SADARI) and perceived benefit for about $83 \%$ or about 15 teenagers already declare that SADARI is a worthwhile behaviour.

However, the results on perceived seriousness and self-efficacy are $50 \%$, or there are merely nine teenagers who considered 
breast cancer a severe illness and thought they could do SADARI behaviour. The preliminary study results turned out different from the study result (Abolfotouh et al., 2015). And the perceived benefit is estimated at $83 \%$, or about 15 teenagers already said that SADARI is healthy behaviour. In a group of 433 respondents, the result has a low score on perceived susceptibility, which is about $44.8 \%$ or 193 respondents, $55.6 \%$ or about 240 of selfefficacy. The analysis result regarding the HBM theory in research is still unclear. As a result, further research needs to be done. Breast cancer is a malignant tumour that can affect the breast area with a total of 2.09 million cases and cause 627,000 deaths globally (Alsaraireh and Darawad 2017).

Ikatan Dokter Indonesia (IDI) indicates that breast cancer is one of the leading causes of death, with about 521,000 cases per 2018 in Indonesia. The estimates of the number of cases of patients are known with number 6 in the Province of Sulawesi with 2,975 cases (Kemenkes 2015). Breast cancer is the most frequent incidence disease at Wahidin Surdirohusodo hospital in Makassar, with 918 people with 95 deaths (Desmy 2017). In Indonesia, nearly $70 \%$ of breast cancer patients would the hospitals when they are in the last stages of cancer (Dewi 2018). Thus, the most essential and recommended strategies for early detection of cancer are mammography, clinical breast examinations Pemeriksaan Payudara Klinis (SADANIS) and Breast Self-Examination (BSE) (Pirzadeh 2018).

Research shows that $90 \%$ of all breast cancer can be detected by the patients themselves if carried out every month (Mohamed, Moey, and Lim 2019). However, because of the lack of perceptiveness regarding breast cancer's vulnerabilities among women, to feel unable to do BSE are some reasons why they have not contributed to screening (Tapera et al. 2019). Generally, women in Indonesia often experience late diagnosis because of inadequate knowledge about breast cancer, breast care and early detection of breast cancer (Tuti 2017). Breast cancer itself can be reduced by applying evidence-based strategies for prevention and early detection. Teenagers grow to maturity starting by the first period (menarche), followed by maturity in breast cells.
Additionally, a study of the population of teens (17-19) by Thomas et al. (2019), mentioned an increase in breast cancer cases to de novo stadium IV in youth. Some of these reasons may be references to why it is important to educate teens about how to perform self-examination (SADARI). Early detection may not entirely prevent breast cancer, but it is so helpful in the early discovery of cases that the success of treatment would be better (American Cancer Society 2014). However, it is important to understand what the youth may not know about breast cancer, perceptions about breast cancer, and the benefits and problems to perform it (Akhtarizavare et al. 2016).

The Health Belief Model (HBM) theory is a theory that focuses on an understanding of someone's perception of changing their behaviour. It has been used very often on BSE research related to teen targets. As with the research done by Mohamed, Moey, and Lim (2019) with a topic BSE (Breast SelfExamination) as early detection of breast cancer, Akhtari-zavare et al. (2016) with a topic awareness of breast health by regularly doing BSE in youth, where the result of research indicates that after the intervention is given, the youth has a positive perception in performing SADARI behaviour. It can be introduced to youth through various health education methods, such as research conducted by Deviani, Citrawati, and Suasti (2018), the outcome there was a significant difference in knowledge about SADARI using methods of speech and demonstration. Furthermore, by using a brainstorming method Maharani, Wati, and Sariati (2019) conclude that there has been an increase in perception after post-test, but research done by Ulfa and Azrida (2018) by the method of speech and Aeni and Yuhandini (2018) by demonstrating methods, there is no significant difference in knowledge before and after counselling.

The combination of the LBD method has been used previously by Habibi (2016) on maternal behaviour in complementary feeding with positive results, which can improve maternal behaviour in complementary feeding. The LBD method can provide a picture of positive behaviour because of its more specific procedures. After providing education to respondents with the lecturer method, 
researchers can brainstorm. The purpose of brainstorming is to find out about the understanding that respondents get from the lecture method. Researchers and respondents can exchange opinions and equate perceptions. Finally, to improve the respondent's ability, in this case, BSE, a demonstration method was carried out so that each respondent could do it directly and find out where their mistake was. Research on the effect of LBD on BSE behaviour in adolescent girls has never been studied, so researchers are interested in using these three methods. Based on the HBM theory with various methods, the increase in BSE behaviour in adolescents is still unclear to affect variables and requires further research.

\section{METHOD}

\section{Study Design}

The study used a quantitative research design with the Quasi-Experiment design of pre-test, post-test and control design. In this study, the two groups established by researchers will be given pre-tests initially, and after the interventions are given to the group, both groups will be run post-test.

\section{Population, Samples, and Sampling}

The target population in this study is the entire female students of Senior High School 3 GOWA, South Sulawesi, with 519 students in the November-December 2019 period. The sample in this study is students in their XII grade with the capacity of 54 respondents using nonProbability sampling techniques by purposivesampling method and then divide into two groups that are treatment and control groups with 27 respondents each of them.

\section{Instruments}

In this study, the instrument used was a questionnaire tested for validity and reliability by Andririanti (2015) on respondents who had the same characteristics as the research respondents. The components of this questionnaire include several statements regarding perceived severity, perceived barriers, perceived benefits, perceived susceptibility and self-efficacy, which are measured using an ordinal scale, namely high scores with $76-100 \%$ results, moderate 60 $75 \%$, and low if $<60 \%$. In addition, there is an observation sheet for breast self-examination (BSE) consisting of 10 statements. The assessment of this observation sheet uses a Likert scale made in the form of answer choices, namely if Good $=3$ and Enough $=2$. The results of the assessment are interpreted, if the number of values $<75 \%$ is included in the criteria is sufficient and if the total value $>76 \%$ is included in the good criteria.

Table 1. Characteristics of respondents

\begin{tabular}{lllll}
\hline Characteristic & \multicolumn{2}{c}{ Treatment Group } & Control Group \\
\cline { 2 - 5 } & $\mathbf{n}$ & $\mathbf{0}$ & $\mathbf{n}$ & $\mathbf{\%}$ \\
\hline Age & & & & \\
16 years old & 19 & 70.4 & 3 & 11.1 \\
17 years old & 8 & 29.6 & 16 & 59.3 \\
18 years old & 0 & 0 & 8 & 29.6 \\
Media Source about SADARI & & & & 3.7 \\
Friends/neighbours & 1 & 3.7 & 1 & 11.1 \\
Health care services & 0 & 0 & 3 & 14.8 \\
Internet/Social network & 2 & 7.4 & 4 & 7.4 \\
TV-Radio & 1 & 3.7 & 2 & 63.0 \\
Nothing & 22 & 81.5 & 17 & 11.1 \\
The risk of breast cancer & & & & 25.9 \\
Gen & 1 & 3.7 & 3 & 7.4 \\
Menarche in <12 Years old & 1 & 3.7 & 7 & 55.6 \\
Breast radiation history (X-ray) & 2 & 7.4 & 2 & 15 \\
Nothing & 22 & 81.5 & & \\
\hline
\end{tabular}




\section{Procedure}

First, the researcher submitted a preliminary data collection permit application to the Academic Department of the Faculty of Nursing, Airlangga University, and the Principal of State Senior High School 3 Gowa. After obtaining permission, the researchers conducted preliminary data collection at Senior High School 3 Gowa on October 23, 2019 , by conducting youth interviews for population data. The data is then stated in a research proposal as a result of a preliminary study. Furthermore, the researchers conducted a proposal seminar on November 08,2019 , and a test on November 26, 2019, conducted at the Faculty of Nursing, Airlangga University with number: 1870- KEPK. The implementation process begins with submitting a data collection permit application to the Principal of Senior High School 3 Gowa and then collecting respondents in one room.

Furthermore, the researcher introduced himself, carried out informed consent, and explained the benefits and objectives of the study. If the respondents agreed, they were asked to sign a signature. Then in the witness section, it was signed by their homeroom teacher. Then the researcher divided the respondents into two groups, namely the treatment group and the control group. Where in each group, there are 27 girls with a total of 54 girls. After that, the researchers conducted a pre-test for both groups by asking them to fill out a questionnaire that had been prepared. The pre-test results will show the perception and level of knowledge of all respondents about BSE behaviour.

Finally, the control group will be given a leaflet before leaving the room. In the treatment group, researchers provided interventions sequentially based on the LBD method of health education (lectures, brainstorming, and demonstrations). The lecture method was carried out on the first day, followed by the brainstorming method in 3 small groups. On the second day, the demonstration method was carried out in all treatment groups. After nine days, post-tests were carried out in both groups. Finally, the researchers then provided health education with the same approach to the control group.

\section{Data Analysis}

Analyze the data using the statistical test from Mann Whitney U Test and Wilcoxon Sign Rank Test.

\section{Ethical Clearance}

The ethical test was conducted on November 26,2019 , which was conducted at the Faculty of Nursing, Airlangga University with No: 1870-KEPK

\section{RESULTS}

The overall result of this study on Perceived Susceptibility variables is, there an influence on LBD giving on the Perceived Susceptibility of teens regarding SADARI with data $\mathrm{p}<0.05$. In the perceived severity variable, the analysis is $p<0.05$, which means there is an LBD build of teens towards perceived severity. While for the perceived barrier variable, the analysis is $p>0.05$, which means there is no significant impact on LBD's giving to young women's SADARI behaviour. The variable perceived benefit analysis is $\mathrm{p}<0.05$, which means there is an LBD effect on the teen about SADARI. Finally, in the self-efficacy, the variable is $\mathrm{p}<$ 0.05 , which means there is an LBD effect on the increased self-efficacy of teens in doing SADARI.

Table 1 describes the characteristics of all respondents in terms of age with results. The majority of respondents from both groups were 17 years old (44.4\%), with a total of 24 people. However, the treatment group was dominated by respondents aged 16 years, amount to 19 respondents (70.4\%). Sources of information regarding Breast Self Examination indicate that most respondents have never received information about BSE in all groups. Based on the risk of breast cancer, 22 respondents $(81.5 \%)$ in the treatment group and 15 respondents $(55.6 \%)$ chose no risk of breast cancer.

Based on table 2, the perceived susceptibility of respondents in the treatment group during the pre-test was primarily low, 26 respondents (96.3\%), while of the post-test, 16 respondents $(59.3 \%)$ had high perceived susceptibility. However, two respondents are still in the low category, where according to demographic data, the source of information 
Table 2. Perceived susceptibility of adolescents regarding breast cancer before and after being given health education by LBD

\begin{tabular}{|c|c|c|c|c|c|c|c|c|}
\hline \multirow{3}{*}{ Perceived Susceptibility } & \multicolumn{4}{|c|}{ Treatment Group } & \multicolumn{4}{|c|}{ Control Group } \\
\hline & \multicolumn{2}{|c|}{ Pre } & \multicolumn{2}{|c|}{ Post } & \multicolumn{2}{|c|}{ Pre } & \multicolumn{2}{|c|}{ Post } \\
\hline & $\mathbf{n}$ & $\%$ & $\mathbf{n}$ & $\%$ & $\mathbf{n}$ & $\%$ & $\mathbf{n}$ & $\%$ \\
\hline Low & 26 & 96.3 & 3 & 11.1 & 26 & 96.3 & 21 & 77.8 \\
\hline Medium & 1 & 3.7 & 8 & 29.6 & 1 & 3.7 & 4 & 14.8 \\
\hline High & 0 & 0 & 16 & 59.3 & 0 & 0 & 2 & 7.4 \\
\hline Wilcoxon Sign Rank Test & \multicolumn{4}{|c|}{$\mathrm{p}=0.000$} & \multicolumn{4}{|c|}{$\mathrm{p}=0.000$} \\
\hline Mann Whitney U Test & \multicolumn{8}{|c|}{$p=0.000$} \\
\hline
\end{tabular}

Table 3. Perceived severity of adolescents regarding breast cancer before and after being given health education by LBD

\begin{tabular}{|c|c|c|c|c|c|c|c|c|}
\hline \multirow{3}{*}{ Perceived Severity } & \multicolumn{4}{|c|}{ Treatment Group } & \multicolumn{4}{|c|}{ Control Group } \\
\hline & \multicolumn{2}{|c|}{ Pre } & \multicolumn{2}{|c|}{ Post } & \multicolumn{2}{|c|}{ Pre } & \multicolumn{2}{|c|}{ Post } \\
\hline & $\mathbf{n}$ & $\%$ & $\mathbf{n}$ & $\%$ & $\mathbf{n}$ & $\%$ & $\mathbf{n}$ & $\%$ \\
\hline Low & 17 & 63.0 & 5 & 18.5 & 12 & 44.4 & 19 & 70.4 \\
\hline Medium & 5 & 18.5 & 12 & 44.4 & 9 & 33.3 & 8 & 29.6 \\
\hline High & 5 & 18.5 & 10 & 37.0 & 6 & 22.2 & 0 & 0 \\
\hline Wilcoxon Sign Rank Test & \multicolumn{4}{|c|}{$\mathrm{p}=0.000$} & \multicolumn{4}{|c|}{$\mathrm{p}=0.001$} \\
\hline Mann Whitney U Test & \multicolumn{8}{|c|}{$\mathrm{p}=0.000$} \\
\hline
\end{tabular}

Table 4. Perceived barrier of adolescents regarding breast cancer before and after being given health education by LBD

\begin{tabular}{|c|c|c|c|c|c|c|c|c|}
\hline \multirow{3}{*}{ Perceived Barrier } & \multicolumn{4}{|c|}{ Treatment Group } & \multicolumn{4}{|c|}{ Control Group } \\
\hline & \multicolumn{2}{|c|}{ Pre } & \multicolumn{2}{|c|}{ Post } & \multicolumn{2}{|c|}{ Pre } & \multicolumn{2}{|c|}{ Post } \\
\hline & $\mathbf{n}$ & $\%$ & $\mathbf{n}$ & $\%$ & $\mathbf{n}$ & $\%$ & $\mathbf{n}$ & $\%$ \\
\hline Low & 25 & 92.6 & 2 & 7.4 & 6 & 22.2 & 14 & 51.9 \\
\hline Medium & 2 & 7.4 & 7 & 25.9 & 19 & 70.4 & 10 & 37.0 \\
\hline High & 0 & 0 & 18 & 66.7 & 2 & 7.4 & 3 & 11.1 \\
\hline Wilcoxon Sign Rank Test & \multicolumn{4}{|c|}{$\mathrm{p}=0.000$} & \multicolumn{4}{|c|}{$\mathrm{p}=0.001$} \\
\hline Mann Whitney U Test & \multicolumn{8}{|c|}{$p=0.000$} \\
\hline
\end{tabular}

about BSE is not available. Whereas in the control group, two respondents increased into the high category. The results of the Wilcoxon Sign Rank Test analysis in the treatment group and the control group obtained a $\mathrm{p}<0.05$, which means there is an effect of LBD

Based on table 3 , the results show that the perceived severity of respondents in the two groups at the time of pre-test mostly had low perceptions. The rising parameter is If I ever have breast cancer, I will feel incomplete as a woman. The Wilcoxon Sign Rank Test analysis results in the treatment group obtained $\mathrm{p}<$ 0.05 , which means a significant effect of LBD on adolescent perceived severity regarding BSE, which is significant during the pre-test and post-test. The Mann Whitney U test analysis results showed that LBD significantly affected adolescent perceived severity regarding BSE treatment and control groups after giving treatment.

Based on table 4, the perceived barrier of respondents in both groups during the pretest mainly was in a low category. There was an increase in perceived barriers in the treatment group, namely the respondents initially in the medium and high category to below. Whereas in the control group, there was also an increase where respondents who were originally in the medium category became low. The Wilcoxon Sign Rank Test analysis results in the two groups were obtained $\mathrm{p}>0.05$, which means 
that there is no significant effect of LBD on the perceived barrier of adolescents regarding BSE during pre and post-test. On the other hand, the Mann Whitney U Test analysis obtained $p<0.05$, which means that there is a significant effect of LBD on the perceived barrier of adolescents regarding BSE between the treatment and control groups after administration.

Based on table 5, the perceived benefits of respondents in the treatment group during the pre-test mainly were low. There were 18 respondents in the treatment group that has increased into the high category. While in the control group, there were six respondents from the low to the high category. Analysis results The Wilcoxon Sign Rank Test in the treatment group and the control group obtained a p < 0.05 , which means a significant effect of LBD on adolescent perceived benefits regarding BSE during the pre and post-test. The results of the Mann Whitney U Test analysis obtained $p<0.05$, which means that there is a significant effect of LBD on the perceived benefits of adolescents regarding BSE treatment and control groups

Based on table 6, the respondents perceived self-efficacy in the treatment group during the pre-test was primarily low, namely as many as 22 respondents (81.5\%). The Wilcoxon Sign Rank Test analysis results in the treatment group obtained $\mathrm{p}<0.05$, which means that there is a significant difference in

Table 5. Perceived benefit of adolescents regarding breast cancer before and after being given health education by LBD

\begin{tabular}{|c|c|c|c|c|c|c|c|c|}
\hline \multirow{3}{*}{ Perceived Benefit } & \multicolumn{4}{|c|}{ Treatment Group } & \multicolumn{4}{|c|}{ Control Group } \\
\hline & \multicolumn{2}{|c|}{ Pre } & \multicolumn{2}{|c|}{ Post } & \multicolumn{2}{|c|}{ Pre } & \multicolumn{2}{|c|}{ Post } \\
\hline & $\mathbf{n}$ & $\%$ & $\mathbf{n}$ & $\%$ & $\mathbf{n}$ & $\%$ & $\mathbf{n}$ & $\%$ \\
\hline Low & 21 & 77.8 & 2 & 7.4 & 22 & 81.5 & 11 & 40.7 \\
\hline Medium & 4 & 14.8 & 5 & 18.5 & 5 & 18.5 & 10 & 37.0 \\
\hline High & 2 & 7.4 & 20 & 74.1 & 0 & 0 & 6 & 22.2 \\
\hline Wilcoxon Sign Rank Test & \multicolumn{4}{|c|}{$\mathrm{p}=0.000$} & \multicolumn{4}{|c|}{$\mathrm{p}=0.000$} \\
\hline Mann Whitney U Test & \multicolumn{8}{|c|}{$\mathrm{p}=0.000$} \\
\hline
\end{tabular}

Table 6. Perceived self-efficacy of adolescents regarding breast cancer before and after being given health education by LBD

\begin{tabular}{|c|c|c|c|c|c|c|c|c|}
\hline \multirow{3}{*}{ Perceived Self-Efficacy } & \multicolumn{4}{|c|}{ Treatment Group } & \multicolumn{4}{|c|}{ Control Group } \\
\hline & \multicolumn{2}{|c|}{ Pre } & \multicolumn{2}{|c|}{ Post } & \multicolumn{2}{|c|}{ Pre } & \multicolumn{2}{|c|}{ Post } \\
\hline & $\mathbf{n}$ & $\%$ & $\mathbf{n}$ & $\%$ & $\mathbf{n}$ & $\%$ & $\mathbf{n}$ & $\%$ \\
\hline Low & 22 & 81.5 & 0 & 7.4 & 27 & 100 & 23 & 85.2 \\
\hline Medium & 5 & 18.5 & 10 & 37.0 & 0 & 0 & 4 & 14.8 \\
\hline High & 0 & 0 & 17 & 63.0 & 0 & 0 & 0 & 0 \\
\hline Wilcoxon Sign Rank Test & \multicolumn{4}{|c|}{$\mathrm{p}=0.000$} & \multicolumn{4}{|c|}{$\mathrm{p}=0.000$} \\
\hline Mann Whitney U Test & \multicolumn{8}{|c|}{$\mathrm{p}=0.000$} \\
\hline
\end{tabular}

Table 7. SADARI practice of adolescents regarding breast cancer before and after being given health education by LBD

\begin{tabular}{|c|c|c|c|c|c|c|c|c|}
\hline \multirow{3}{*}{ SADARI Practice } & \multicolumn{4}{|c|}{ Treatment Group } & \multicolumn{4}{|c|}{ Control Group } \\
\hline & \multicolumn{2}{|c|}{ Pre } & \multicolumn{2}{|c|}{ Post } & \multicolumn{2}{|c|}{ Pre } & \multicolumn{2}{|c|}{ Post } \\
\hline & $\mathbf{n}$ & $\%$ & $\mathbf{n}$ & $\%$ & $\mathbf{n}$ & $\%$ & $\mathbf{n}$ & $\%$ \\
\hline Less & 27 & 100 & 0 & 0 & 27 & 100 & 2 & 7.4 \\
\hline Enough & 0 & 0 & 1 & 3.7 & 0 & 0 & 25 & 92.6 \\
\hline Good & 0 & 0 & 26 & 96.3 & 0 & 0 & 0 & 0 \\
\hline Wilcoxon Sign Rank Test & \multicolumn{4}{|c|}{$\mathrm{p}=0.000$} & \multicolumn{4}{|c|}{$\mathrm{p}=0.000$} \\
\hline Mann Whitney U Test & \multicolumn{8}{|c|}{$\mathrm{p}=0.000$} \\
\hline
\end{tabular}


perceived self-efficacy during the pre-test and post-test. Whereas in the control group, the value of $p<0.05$ means a significant effect of LBD on adolescents' perceived self-efficacy regarding BSE during the pre and post-test. The results of the Mann Whitney $U$ Test analysis obtained $\mathrm{p}<0.05$, which means that there is a significant effect of LBD on adolescent perceived self-efficacy regarding BSE

Based on table 7, the practice of BSE respondents in the treatment group during the pre-test were all in the poor category because the respondents could not do BSE. Still, at the time of the post-test, 26 respondents (96.3\%) were in the good category of doing BSE. The Wilcoxon Sign Rank Test analysis results in the treatment and control groups obtained $p<0.05$, which means that there is a significant effect of LBD on BSE in adolescents during the pre-test and post-test. In addition, the Mann Whitney U Test analysis results obtained $\mathrm{p}<0.05$, which means that there is a significant effect of LBD on BSE in adolescents between the treatment and control groups after treatment.

\section{DISCUSSION}

Research indicates that teenage perceived susceptibility before any treatment and leaflet, the majority of respondents are in a low category. According to the results of demographic data, in which respondents never get any information about SADARI. Knowledge of breast cancer can significantly affect the increase of breast cancer screening awareness (Hardiyanti 2018). The post-test results on the treatment group obtained Perceived of Susceptibility because the responders felt that they had the possibility of breast cancer. LBD's health education methods prove influential in enhancing youth perceived susceptibility in applying SADARI behaviour based on the value of its significance $p<0.05$. Delviani and Pricilla (2014) found that students positively perceive their vulnerability to breast cancer based on past experiences and acquired education.

Studies have shown that perceived severity levels after LBD methods applied have increased. Most of the respondents strongly agreed that 'if I get breast cancer someday I will feel incomplete as a woman', which would be good to improve SADARI behaviour. Besides having information about being aware, there is a family of respondents with a history of breast cancer. The family is the closest relative to a teenager, the family member with breast cancer has passed through a phase where he feels signs and symptoms right down to the treatment of breast cancer. Such conditions can affect adolescents as they have seen the severity of breast cancer. Akhtari-zavare et al. (2016) mentioned that knowledge, belief, and attitudes about illness are important factors in either doing or not performing SADARI behaviour. When a person is unaware of the severity of breast cancer, his perceptions tend to be low (Nugrahani Rizqi, Budihastuti, and Pamungakasari 2017).

The researchers have reported that after the LBD treatment group method, the perceived barrier has decreased in most of the respondents. Youth are convinced to overcome detention by implementing SADARI behaviour. Studies confirm that after the LBD method of treatment groups, the perceived benefit is increasing by teenagers who strongly agree that self - examinations have many benefits. A study conducted by Delviani and Pricilla (2014) found a relationship between perception of the benefits and SADARI behaviour in the Faculty of nursing of Andalas after treatment. It is in line with research done by Septa (2011) that perceptions of the benefits regarding SADARI rise because respondents can answer the questions provided. However, it is also expected that students will be more active in learning reproductive health information, in particular, SADARI, outside the school environment through books and advertisements for public services.

The study outcomes reported that after a given intervention of health education using the LBD method, most students developed a positive perception of SADARI behaviour. According to the parameters of most of the respondents in the high category already in favour of increasing perceived self-efficacy towards SADARI behaviour is proved by that 'I can get my breast exam correctly'.

Solehati et al. (2019) suggest that education or health education affects 89 people's behaviour to carry out SADARI. Therefore, the LBD method of elevating adolescents' awareness, particularly selfefficacy, can be developed as a preventive measure against breast cancer. In addition, 
research shows an LBD effect on young women's SADARI behaviour in which SADARI re-demonstration, a suitable category of treatment groups capable of doing SADARI properly.

\section{CONCLUSION}

Delivering LBD health education methods can boost perceived susceptibility, perceived severity, perceived barrier, perceived benefit, perceived self-efficacy of teenagers regarding SADARI behaviour. Teenagers are given health education to increase their knowledge of breast cancer. The health education including the risk factors of breast cancer, the severity of the disease, and the effect it has on the lives of the patients and family, the application of SADARI behavior as an effort to early detection of breast cancer, problems that may occur in applying SADARI, the benefit of SADARI, and the boost of confidence that a teenager is also able to detect a breast disorder by being aware. Further, performing health education using phantom media can improve the youth's skills of SADARI behaviour in accordance with the correct stages.

\section{ACKNOWLEDGMENT}

I would like to thank Head of senior high school 3 Gowa and the participants who participated in this study.

\section{CONFLICT OF INTEREST}

There are no conflicts in the research.

\section{REFERENCES}

Abolfotouh, Mostafa A, Ala A Banimustafa, Aisha A Mahfouz, and Mohammed $\mathrm{H} \mathrm{Al}$-assiri. 2015. "Using the Health Belief Model to Predict Breast Self Examination among Saudi Women." BMC Public Health: 1-12. http://dx.doi.org/10.1186/s12889-0152510-y.

Aeni, Nurul, and Diyah Sri Yuhandini. 2018. "Pengaruh Pendidikan Kesehatan Dengan Media Video Dan Metode Demonstrasi Terhadap Pengetahuan SADARI." (2): 162-74.

Akhtari-zavare, Mehrnoosh, Muhamad Hanafiah Juni, Salmiah Said, and
Irmi Zarina Ismail. 2016. "Result of Randomized Control Trial to Increase Breast Health Awareness among Young Females in Malaysia." BMC Public Health: 1-11. $\quad$ http://dx.doi.org/10.1186/ s12889-016-3414-1.

Alsaraireh, Arwa, and Muhammad W Darawad. 2017. "Impact of a Breast Cancer Educational Program on Female University Students' Knowledge , Attitudes , and Practices."

American Cancer Society. 2014. "Breast Cancer Early Detection: Breast Cancer Prevention and Early Detection."

Delviani, R., and V. (2014). Pricilla. 2014. "Persepsi Mahasiswi Tentang Kanker Payudara Dan Perilakunya Terhadap Pencegahan Kanker Payudara Di Fakultas Keperawatan Universitas Andalas." Jurnal Keperawatan.

Desmy, Fadillah. 2017. "Insidensi Penyakit Kanker Skripsi Desember 2017 Di RSUP Dr. Wahidin Sudirohusodo Makassar Periode Januari 2015 - Juni 2017."

Deviani, Ni Luh Putu, Ni Ketut Citrawati, and Ni Made Adi Suasti. 2018. "Efektivitas Pendidikan Kesehatan dengan Metode Ceramah dan Demonstrasi terhadap Peningkatan Pengetahuan tentang Deteksi Dini Kanker Payudara Pada Remaja Putri." 5: 50-65.

Dewi, Triana Kesuma. 2018. "Validation of the Indonesian Version of Champion' $s$ Health Belief Model Scale for Breast SelfExamination.": 433-38.

Habibi, Anna Nurwachidah Rois. 2016. "The Influence of CBD (Ceramah, Brainstorming, Demonstrasi) Method towards Mother's Behaviour in Giving Complementary Feeding Towards Baby Aged 6-24 Months.": 24.

Hardiyanti, Diana. 2018. "Pengaruh Pendidikan Kesehatan Berbasis Komunitas Terhadap Pengetahuan, Sikap Dan Praktik Pemeriksaan Payudara Sendiri (SADARI) Pada Perempuan Di Wilayah Puskesmas Martapura 1." http://repository.unair. ac.id/77134/2/TKP 34_18 Har p.pdf.

Kemenkes. 2015. "Situasi Penyakit Kanker."

Kıssal, Aygül, and Bahtısen Kartal. 2019. "Effects of Health Belief Model - Based Education on Health Beliefs and Breast Self - Examination in Nursing Students.": 
403-10.

Maharani, Sri Ayu, Linda Ratna Wati, and Yuseva Sariati. 2019. "Perbandingan Efektivitas Metode Brain Storming Dan Simulation Game Terhadap Peningkatan Pengetahuan Kanker Payudara Pada Siswi Kelas XII SMAN 4 Malang." : 33-47.

Mohamed, Norfariha Che, Soo-foon Moey, and Bee-chiu Lim. 2019. "Validity and Reliability of Health Belief Model Questionnaire for Promoting Breast SelfExamination and Screening Mammogram for Early Cancer Detection." 20: 2865-73.

Nugrahani Rizqi, Rosi, Uki Retno Budihastuti, and Eti Poncorini Pamungakasari. 2017. "Health Belief Model on the Factors Associated with the Use of HPV Vaccine for the Prevention of Cervical Cancer among Women in Kediri, East Java." Journal of Epidemiology and Public Health 02(01): 70-81.

Pirzadeh, Asiyeh. 2018. "Application of the Health Belief Model in Breast Self-Examination by Iranian Female University Students." 11(3).

Septa, Nurmalia. 2011. "Gambaran Persepsi tentang Sadari pada Siswi Kelas II Di SMPN 1 Banguntapan Bantul Yogyakarta."

Solehati, Tetti et al. 2019. "Jurnal Keperawatan Muhammadiyah Pengaruh Pendidikan
Kesehatan Terhadap Perilaku Melakukan Sadari Pada Wanita Usia Subur: Literature Review." 4(2): 193-205.

Tapera, Roy et al. 2019. "The Use of the Health Belief Model (HBM) in Determining the Factors Associated with Breast Cancer Screening among Female Students in Botswana." International Journal of Health Promotion and Education 57(4): 203-16. https://doi.org/10.1080/1463 5240.2019.1601026.

Thomas, Alexandra et al. 2019. "Incidence and Survival Among Young Women With Stage I - III Breast Cancer : SEER 2000 2015." 3: 1-9.

Tuti, Pahria. 2017. "Indonesian Women Diagnosed with Breast Cancer: A Hermeneutic Process."

Ulfa, Siti Mutia, and Rinna Azrida. 2018. "Efektivitas Penyuluhan Pemeriksaan Payudara Sendiri (Sadari) dengan Metode Ceramah dan Video Terhadap Tingkat Pengetahuan Tentang Deteksi Dini Kanker Payudara Pada Remaja Putri Di SMS Muhammadiyah 01 Medan Tahun 2016." 2(2): 144-51.

Yani, Widyastuti. 2009. Kesehatan Reproduksi Kesehatan Reproduksi. Yogyakarta: Fitrimaya. 